vol.6. No.1 - 2019

\title{
THE RELATIONSHIP BETWEEN LEADERSHIP STYLES AND NURSING STAFF LOYALTY AT MANSOURA HEALTH INSURANCE HOSPITAL \\ ${ }^{1}$ Sadiaa El shabrawy El sherbeny, ${ }^{2}$ Abeer Mohamed Zakaria, ${ }^{3}$ Eltahara Elsayed Abo Habeb \\ ${ }^{1}$ Nursing specialist, ${ }^{2}$ Professor of Nursing Administration, ${ }^{3}$ Lecturer of Nursing Administration Faculty of Nursing, Mansoura University \\ E-mail: sadia.elshabrawi@yahoo.com
}

\begin{abstract}
Background: Today, nursing staff's loyalty is one most difficult problems that troubles head nurses. Several ways are proposed to solve this problem, among which improving style of leadership as a key perspective, for that to, leadership style determines the relationship between head nurses and nursing staff . Aim: The study aimed to explore relationship between leadership styles and nursing staff loyalty at Mansoura Health Insurance Hospital. Methods: Descriptive Correlation design study was used and conducted on 300 of staff nurses working at Mansoura Health Insurance Hospital, using two tools: Multifactor Leadership Questionnaire (MLQ) and Loyalty to Head nurse Scale (LS). Results: revealed that there was statistically significant $(\mathrm{P}<0.05)$ correlation between leadership styles and loyalty. The findings of the study showed that nurses will be satisfied when head nurses using transformational leadership style followed by laissez-faire leadership style. Conclusion: the study concluded that there is statistical significant correlation between head nurses' leadership styles and nursing staff loyalty at Mansoura Health Insurance Hospital. Recommendation: The head nurse should know the necessary element for the nursing staff and the hospitals and stimulate the nursing staff to search the opportunities around them effectively. The hospital and head nurses should share the decisions and the leadership with the nursing staff. Beside, present the training and facilitation for the team. In addition, The practices and the polices should associated with the feedback system and the rewarding to satisfy the needs of the nursing staff for developing the loyalty for the nurses.
\end{abstract}

Keywords: Leadership Styles, Nursing Staff loyalty.

\section{Introduction:}

Nowadays, in the tight labor market, keeping good nurses and developing nursing staff loyalty becomes increasingly important and a continuing challenge. So, the head nurse's Leadership style involves the use of interpersonal skills to influence nursing staff to accomplish a specific goal (Sullivan and Garland, 2010). According to this reason the hospital should emphasize evolving the management of the leadership skills for controlling the relations between head nurse and nursing staff. Therefore, it is essential important to make the relations between head nurse and nursing staff whose would like to be respected by head nurses. Head nurse's leadership style helps to create a positive work environment, enhancing nursing staff' sense of belonging and loyalty to the hospital. Head nurses who cultivate harmonious relationships by promoting nursing staff' career development will efficiently improve their hospital commitment and loyalty (Voon, 2011).

The head nurses are the most important piece because nursing staff have to interact with head nurse every day. If the head 
nurse is someone they don't like, she makes them miserable and, less likely to enjoy their job. If the head nurse is someone they respect, she makes them like their job better and promote the loyalty of nursing staff. The head nurse supervises quality of nursing activities during giving report, rounds, making different assignments, conferences and demonstrations. Furthermore, the head nurses have the responsibility for the groups in different departments in the hospital and they should own nurses working in the group (Coughlan, 2005). Head nurses' behavior helps nursing staff adapt to their work's environment, enhance their hospital commitment, and thus reduce their turnover intention (Jaramillo \& Grisaffe, 2009).

The leadership style of the head nurses can be important for nursing staff' acceptance of change and in motivating them to achieve a high quality of care (Azaare \& Gross, 2011). Head nurse leadership style not only inspires nursing staff potential to enhance efficiency but also meets their requirements in the process of achieving hospital goals (Lee \& Chuang, 2009). Head nurse leadership styles the most influential factor in job satisfaction. The Head nurse leadership style includes three types: 1) transformational, 2) transactional, and 3) laissez-faire. The Head nurse may use these leadership styles to varying degrees; however, they have a tendency to use characteristics of one style more than the other (Avolio \& Bass, 2004; Bas et al Riggio, 2006, Marshall, 2010).

The transformational leadership depend on making relations and stimulating the members via participating the mission and the vision. Thus, it has the experience for collecting the confidence and to act in a way that inspires others, staff respect and loyalty from letting the team know they are important (Azaare \& Gross, 2011). Transactional leadership emphasizes on the leaders who practice many transactions in the work in every day. It focuses on making the relations with the nurses, interchange the benefits, revealing the rewarding and penalty with the responsibility sense for achieving the task (Azaare \& Gross, 2011).

Laissez-faire Leadership is a style in which the leader provides little or no direction or supervision, and prefers to take a hands-off approach. Decisions are not made, changes rarely occur, and quality improvement is typically reactive, not proactive (Messmer \& Turkel, 2010). The passive leadership refers to the leaders who neglect the progress in the work and make decision making (Bass \& Avolio, 2004). Leadership style is a type of relationship by which the head nurse uses his rights and methods to influence many nurses to work together in pursuit of a common goal. Head nurse leadership style in the hospital is one of the factors that play significant role in enhancing or retarding the interest and loyalty of the nursing staff in the hospital (Glantz, 2002).

Nursing staff loyalty to head nurses is an important indicator and a concept that refers to the extent of commitment of the nurses in their work and the realizing of the head nurses of the responsibility in the work. (Coughlan, 2005). Nursing staff 'loyalty is one of the major responsibilities of the head nurses thus, the head nurse should have positive attitudes toward their nurses and they should have managerial and leadership skills to promote and maintain their nurses' loyalty and commitment (Messmer \& Turkel, 2010). Loyalty is the willingness of the nursing staff invests in or sacrifices for the hospital to strengthen relationship between them and head nurse. Furthermore, head nurse support, teamwork, and working environment play crucial roles and significantly affect nursing staff loyalty to head nurses.(Phaneuf, 2013). 
THE RELATIONSHIP BETWEEN LEADERSHIP STYLES etc...

Loyalty has two dimensions: internal and external. The internal dimension is the emotional component, it includes feelings of caring, of affiliation and of commitment. This is the dimension that must be nurtured. The external dimension has to do with the way loyalty manifests itself. This dimension is comprised of the behaviors that display the emotional component and is the part of loyalty that changes the most (LaMalfa and Expert, 2007).

\section{Significance of the Study}

The management of the hospital has the problem that is bad relationship between the nursing and the head nurses. This problem is that nurses reported their dissatisfaction with their relationships with the head nurses due to the head nurses leadership style. The nursing staff finds the difficulty in the style of the leadership that lead to weakening the loyalty of the nurses to their head nurses and bad affecting the performance, the productivity in the hospital. Thus, building effective relationship between head nurse and nursing staff should enhance the loyalty to the workplace and its leadership among a group of nurses at Mansoura Health Insurance Hospital.

\section{Aim of the Study}

The study aimed to explore relationship between head nurses' leadership styles and nursing staff loyalty at Mansoura Health Insurance Hospital through:-

- Determining head nurses' leadership styles at Mansoura Health Insurance Hospital.

- Identifying levels of nursing staff loyalty at Mansoura Health Insurance Hospital.

- Exploring relation between leadership styles and nursing staff loyalty.

\section{1) Research Questions}

- What's leadership styles at Mansoura Health Insurance Hospital?
- What are levels of nursing staff loyalty at Mansoura Health Insurance Hospital?

- How do the leadership styles and loyalty to head nurse associated with each other?

\section{Subject and Methods}

Research design:-

The researcher used the descriptive design to carry out this study.

\section{The Setting of the study:}

This study was conducted at Mansoura Health Insurance Hospital that affiliated to General Authority For Health Insurance. This hospital presented at north east of Delta region, provides care for all patients who have health insurance (governmental employees, pensions, widows, and newborn babies). Total hospital bed capacity (360) beds and consists of seven floors. Subjects of the study

The study sample involved all available staff nurses at the period of the study, there number were (240) staff nurses and (37) head nurse with at least one year of experience to be oriented for working conditions, able to express about her opinion

\section{Tool of data collection:}

Data collection tools were including two tools:

Tool 1 -Multifactor Leadership Questionnaire (MLQ) developed by (Bass \& Avolio, 2004) it used to measures head nurse's leadership styles and behaviors.

This tool was consisted of two parts as follow:-

Part I:- Personal characteristics Include age, marital status, educational qualification, experience and department. Part II:- that describes three leadership styles and consist of 45 items it categories into three head nurse's leadership styles, transformational, transactional and Laissez-faire leadership it also measures outcome of leadership. 
Sadiaa El shabrawy El sherbeny et., al.

\begin{tabular}{|c|c|c|c|c|}
\hline Leadership styles & $\begin{array}{l}\text { No of } \\
\text { items }\end{array}$ & $\begin{array}{l}\text { Low } \\
(<50 \%)\end{array}$ & $\begin{array}{l}\text { Moderate } \\
(50 \%->75 \%)\end{array}$ & $\begin{array}{l}\text { High } \\
(\geq 75 \%)\end{array}$ \\
\hline Transformational & 20 & $0-39$ & $40-59$ & $60-80$ \\
\hline Transactional & 8 & $0-15$ & $16-23$ & $24-32$ \\
\hline Laisezz faire & 8 & $0-15$ & $16-23$ & $24-32$ \\
\hline Extra effort & 3 & $0-5$ & $6-8$ & $9-12$ \\
\hline Effectiveness & 4 & $0-7$ & $8-11$ & $12-16$ \\
\hline Satisfaction & 2 & $0-3$ & $4-5$ & $6-8$ \\
\hline Total outcome & 9 & $0-17$ & $18-26$ & $27-36$ \\
\hline
\end{tabular}

Tool 2-Loyalty to Head nurse Scale (LS) developed by (Chen, Tsui, \& Farh in 2002). The aim of this tool was to measure nursing staff loyalty to their head nurses.

This tool was consisted of two parts as follow:-

Part I:- Personal characteristics

Include age, educational qualification, marital status, experience and department.

Table (2): Loyalty scoring system

\begin{tabular}{|l|l|l|l|l|}
\hline Loyalty subscale & $\begin{array}{l}\text { No of } \\
\text { items }\end{array}$ & $\begin{array}{l}\text { Low } \\
(<\mathbf{5 0 \%})\end{array}$ & $\begin{array}{l}\text { Moderate } \\
(\mathbf{5 0} \%-\mathbf{7 5 \%})\end{array}$ & $\begin{array}{l}\text { High } \\
\mathbf{( \geq 7 5 \% )}\end{array}$ \\
\hline Dedication to head nurse & 4 & $0-9$ & $10-14$ & $15-20$ \\
\hline $\begin{array}{l}\text { Extra effort for head } \\
\text { nurse }\end{array}$ & 3 & $0-7$ & $8-11$ & $12-15$ \\
\hline $\begin{array}{l}\text { Attachment to head } \\
\text { nurse }\end{array}$ & 4 & $0-9$ & $10-14$ & $15-20$ \\
\hline $\begin{array}{l}\text { Identification with head } \\
\text { nurse }\end{array}$ & 3 & $0-7$ & $8-11$ & $12-15$ \\
\hline $\begin{array}{l}\text { Internalization of head } \\
\text { nurse's values }\end{array}$ & 3 & $0-7$ & $8-11$ & $12-15$ \\
\hline Total loyalty & 17 & $0-42$ & $43-62$ & $63-85$ \\
\hline
\end{tabular}

Scoring system of the tools: principles, internet, and magazines for

We collected the score of items, then multiplied the total score of items, the percent was given, and give it cut of point. Total scores were calculated and classified into three levels (low $<50 \%$, moderate from $50 \%$ to $75 \%$ and high $>75 \%$ ).

\section{The Preparatory stage:}

This stage included the literature review that related to the study, and the goal is acquiring the theoretical knowledge of the used books, administrative consist of (17 items) it categories into 5 subscales:-

1- dedication to head nurse (4 items), 2more effort for head nurse (3 items), 3 Engagement to head nurse (4 items), 4identification with head nurse (3 items), and 5- internalization of head nurse's values (3 items)

It was measured five points Likert scale ranged from (1) strongly disagree to (5) strongly agree.
Part II:-Loyalty to Head nurse Scale modifying the tool of the data collection. This stage focused on the interpretation, validation and preparation of tool for data collection with administrative preparation to carry out the implementation phase. Reliability test of the study tools were tested by Cronbach's Alpha reliability of the first and the second tool that were computed and found.

\section{The Validity:}




\begin{abstract}
It was designed for proving the validity of the content via five experts in the nursing administration field from Faculty of Nursing at Mansoura University and at Tanta University who checked the instruments for proving the relevance, clarity, applicability and understanding of the study. Moreover, The tools were checked to implement and consistent with their opinions minor modifications were applied. The opinions of the experts for each item were recorded on a two point scale: relevant, not relevant.

Some expertise made modification in translation of tools of data collection, modification in arrangement of tools elements and the final form of the tools.

\section{The Pilot study:}

A pilot study was implemented on $10 \%$ (30 staff nurses)of the whole study sample that was neglected from the main sample (300) staff nurses to check the clarity, feasibility of the questions. Whether they were understandable, and to determine the time needed to fill-in questions, which assess the relationship between head nurses' leadership styles and nursing staff loyalty at Mansoura Health Insurance Hospital. The tools were designed for participants to collect by the researcher.

\section{Field work description:}

An official agreement was obtain from the administrator in by appreciation of the protocol. An information permission for involvement in the study was from the whole study sample. Each nurses may be chosen for completing the study. Tools were translated into Arabic and were checked for the validity from faculty of nursing at Mansoura University and Tanta University.
Collecting data from staff nurses by explaining to participant in the study and take her acceptance. They were reassured that the information given would be utilized confidentially, it would be used only for the research purpose, and the researcher explained to them how to fill in the sheets.

Filling the questionnaire sheets about Multifactor Leadership and Loyalty to head nurse questionnaire. Data collection for some participants was carried out through the distribution of the questionnaire sheet. Field work of this study was carried out in one month from beginning of august to the beginning of September, 2017.

\section{Ethical consideration:}

Prior to the initial interview, explanation of the wildlife. The purpose of the study was by the researcher for the nurses in the study. The researcher got the verbal consent from each nurse who participate in the study before beginning the study.

A certified agreement was attained from the Dean of Faculty of Nursing Mansoura University and from hospital administrator of Mansoura health insurance hospital to conduct the study.

\section{The Statistical Design:-}

By using Statistical Package for Social Science (SPSS, the data and the statistical analysis were carried out) at the version 16.0. The researcher presented the data by using the descriptive design and statistics in the standard deviations. The researcher used the Pearson Correlation coefficient (r) test and p-value for testing the relationship between the variables. The statistical significance was at the value of p-value $<0.05$ and $p$-value of $<0.001$ reveals the high result. 
Sadiaa El shabrawy El sherbeny et., al.

Results

Table (1): Demographic characteristics of the studied sample at Mansoura Health Insurance Hospital

\begin{tabular}{|c|c|c|c|c|}
\hline \multirow[t]{2}{*}{ Variables } & \multicolumn{2}{|c|}{$\begin{array}{c}\text { The studied head } \\
\text { nurses }(n=37)\end{array}$} & \multicolumn{2}{|c|}{$\begin{array}{l}\text { The studied nurses } \\
\qquad(\mathrm{n}=\mathbf{2 4 0})\end{array}$} \\
\hline & No & $\%$ & No & $\%$ \\
\hline \multicolumn{5}{|l|}{ Age (years): } \\
\hline$-20-<31$ & 3 & 8.1 & 145 & 60.4 \\
\hline - 31-40 & 30 & 81.1 & 85 & 35.4 \\
\hline$\cdot>40$ & 4 & 10.8 & 10 & 4.2 \\
\hline Mean (SD) & \multicolumn{2}{|c|}{$36.45(4.1)$} & \multicolumn{2}{|c|}{$29.81(5.83)$} \\
\hline \multicolumn{5}{|l|}{ Experience years } \\
\hline$-1-<6$ & 1 & 2.7 & 82 & 34.2 \\
\hline-6 -10 & 7 & 18.9 & 66 & 27.5 \\
\hline$->10$ & 29 & 78.4 & 92 & 38.3 \\
\hline Mean (SD) & \multicolumn{2}{|c|}{$13.62(4.23)$} & \multicolumn{2}{|c|}{$9.02(5.73)$} \\
\hline \multicolumn{5}{|l|}{ Educational qualification: } \\
\hline - Bachelor degree & 30 & 81.1 & 28 & 11.7 \\
\hline - Technical Diploma of nursing & 7 & 18.9 & 115 & 47.9 \\
\hline - Diploma & 0 & 0.0 & 97 & 40.4 \\
\hline \multicolumn{5}{|l|}{ Marital status } \\
\hline - Single & 0 & 0 & 40 & 16.7 \\
\hline - Married & 37 & 100.0 & 187 & 77.9 \\
\hline - Divorced & 0 & 0.0 & 7 & 2.9 \\
\hline - Widowed & 0 & 0.0 & 6 & 2.5 \\
\hline
\end{tabular}

Table (1): Demographic characteristics of the studied sample this table concerning characteristics of head nurse, the majority $(81.1 \%)$ of head nurses were in age group (31-40) years with mean age 36.45 (4.1) more than $70 \%$ of them had $>10$ years of experience in nursing field with mean years of experience 13.62 (4.23) high percent (81.1) of head nurses had bachelor degree of nursing. All of them married with $100 \%$. While the majority $(60.4 \%)$ of studied nurses were in age group $(20-<30)$ years with mean 29.81 (5.83) more than $30 \%$ of them had $>10$ years of experience in nursing field with mean years of experience 9.02 (5.73) high percent (47.9) of nurses had technical institute of nursing .The majority of them married with $77.9 \%$ 
THE RELATIONSHIP BETWEEN LEADERSHIP STYLES etc...

Table (2): The distinguishing between perception of head nurses and staff nurses regarding leadership styles

\begin{tabular}{|c|c|c|c|c|}
\hline \multirow[t]{2}{*}{ Leadership styles } & $\begin{array}{l}\text { Head nurses } \\
\quad(n=37)\end{array}$ & $\begin{array}{c}\text { Staff nurses } \\
(n=240)\end{array}$ & \multirow[t]{2}{*}{ T-value } & \multirow[t]{2}{*}{$\mathbf{P *}$} \\
\hline & Mean (SD) & Mean (SD) & & \\
\hline $\begin{array}{l}\text { A. Transformational } \\
\text { leadership style } \\
\text { Idealized attributes }\end{array}$ & $6.59(3.34)$ & $7.20(3.23)$ & 1.05 & 0.29 \\
\hline Idealized behaviors & $7.59(3.55)$ & $6.67(3.13)$ & 1.63 & 0.10 \\
\hline Inspirational motivation & $11.16(2.00)$ & $9.92(3.06)$ & 2.37 & $0.01 * *$ \\
\hline Intellectual stimulation & $11.86(2.66)$ & $11.80(3.11)$ & 0.10 & 0.91 \\
\hline Individualized consideration & $10.35(2.96)$ & $9.27(3.50)$ & 1.44 & 0.07 \\
\hline $\begin{array}{l}\text { Total Transformational } \\
\text { leadership style }\end{array}$ & $47.56(7.97)$ & $44.87(9.71)$ & 1.60 & 0.11 \\
\hline $\begin{array}{l}\text { B. Transactional leadership } \\
\text { style } \\
\text { Contingent reward }\end{array}$ & $9.54(2.48)$ & $9.85(2.84)$ & 0.64 & 0.52 \\
\hline $\begin{array}{l}\text { Active management by } \\
\text { exception }\end{array}$ & $10.62(2.00)$ & $9.97(2.39)$ & 1.56 & 0.11 \\
\hline $\begin{array}{l}\text { Total Transactional leadership } \\
\text { style }\end{array}$ & $20.16(3.72)$ & $19.83(4.43)$ & 0.42 & 0.66 \\
\hline $\begin{array}{l}\text { C. Laissez-faire leadership } \\
\text { style } \\
\text { Passive management by } \\
\text { exception }\end{array}$ & $11.08(3.21)$ & $11.10(3.23)$ & 0.48 & 0.96 \\
\hline Laissez-faire leadership & $9.89(1.85)$ & $9.88(2.24)$ & 0.02 & 0.98 \\
\hline $\begin{array}{l}\text { Total Laissez-faire leadership } \\
\text { style }\end{array}$ & $20.97(4.52)$ & $20.99(4.85)$ & 0.02 & 0.98 \\
\hline
\end{tabular}

Table (2): Difference between perception of head nurses and staff nurses regarding leadership styles. This table show that there was statistically significant difference between head nurses and staff nurses regarding inspiration motivation subscale of transformation leadership style $(\mathrm{P}=\mathbf{0 . 0 1} * *)$ but there was no statistically significant difference regarding others domains leadership styles.
Table (3): Total Mean score of loyalty as perceived by the staff nurses $(\mathrm{n}=240)$

\begin{tabular}{|c|c|c|}
\hline $\begin{array}{c}\text { Loyalty subscale } \\
\text { (Each item scored } \\
1-5) \\
\end{array}$ & $\begin{array}{c}\text { Min } \\
- \\
\max \end{array}$ & Mean(SD) \\
\hline $\begin{array}{l}\text { Dedication to head } \\
\text { nurse }\end{array}$ & $\begin{array}{l}4- \\
20 \\
\end{array}$ & $\begin{array}{l}15.74 \\
(3.06) \\
\end{array}$ \\
\hline $\begin{array}{l}\text { Extra effort for } \\
\text { head nurse }\end{array}$ & $\begin{array}{l}3- \\
15\end{array}$ & $\begin{array}{l}12.52 \\
(2.25) \\
\end{array}$ \\
\hline $\begin{array}{l}\text { Attachment } \\
\text { head nurse }\end{array}$ & $\begin{array}{l}4- \\
20\end{array}$ & $\begin{array}{l}15.77 \\
(3.11) \\
\end{array}$ \\
\hline $\begin{array}{l}\text { Identification with } \\
\text { head nurse }\end{array}$ & $\begin{array}{l}3- \\
15\end{array}$ & $\begin{array}{l}11.77 \\
(2.59) \\
\end{array}$ \\
\hline $\begin{array}{l}\text { Internalization of } \\
\text { head nurse's } \\
\text { values }\end{array}$ & $\begin{array}{l}3- \\
15\end{array}$ & $\begin{array}{l}11.56 \\
(2.51)\end{array}$ \\
\hline Total loyalty score & 17 & $\begin{array}{c}67.39 \\
(11.82)\end{array}$ \\
\hline
\end{tabular}


Sadiaa El shabrawy El sherbeny et., al.

Table (3): Total Mean score of loyalty as perceived by the staff nurses at Mansoura Health Insurance Hospital .This table show that the highest Mean score (15.77) regard while the lowest Mean SD $\pm(11.56)$. The

Table (4): level of loyalty subscale as perceived by the staff nurses $(n=240)$

\begin{tabular}{|l|l|l|l|l|l|l|}
\hline \multirow{3}{*}{ Loyalty subscale } & \multicolumn{2}{|l|}{ The studied nurses(n=240) } \\
\cline { 2 - 7 } & \multicolumn{2}{l}{ Low } & \multicolumn{2}{l|}{ Moderate } & \multicolumn{2}{l|}{ High } \\
\cline { 2 - 7 } & No & \% & No & \% & No & \% \\
\hline A. Dedication to head nurse & 14 & 5.8 & 46 & 19.2 & 180 & 75.0 \\
\hline B. Extra effort for head nurse & 10 & 4.2 & 20 & 8.3 & 210 & 87.5 \\
\hline C. Attachment to head nurse & 12 & 5.0 & 42 & 17.5 & 186 & 77.5 \\
\hline D. Identification with head nurse & 21 & 8.8 & 46 & 19.2 & 173 & 72.1 \\
\hline E. Internalization of head nurse's values & 22 & 9.2 & 44 & 18.3 & 174 & 72.5 \\
\hline Total loyalty score & 14 & 5.8 & 35 & 14.6 & 191 & 79.6 \\
\hline
\end{tabular}

Table (4): level of loyalty subscale as perceived by the staff nurses. This table shows the level of loyalty subscale as perceived by staff nurses at Mansoura Health Insurance Hospital. The extra effort

Table (5): correlation matrix between leadership styles and loyalty as perceived by the staff

\begin{tabular}{|c|c|c|c|c|c|c|}
\hline \multirow{2}{*}{ Leadership styles } & Dedication & Extra effort & Attachment & Identification & Internalization & $\begin{array}{l}\text { Total loyalty } \\
\text { score }\end{array}$ \\
\hline & $\mathbf{r}(\mathbf{P})$ & $\mathbf{r}(\mathbf{P})$ & $\mathbf{r}(\mathbf{P})$ & $\mathbf{r}(\mathbf{P})$ & $\mathbf{r}(\mathbf{P})$ & $\mathbf{r}(\mathbf{P})$ \\
\hline $\begin{array}{l}\text { A. } \\
\text { Transformational } \\
\text { leadership style } \\
\text { Idealized attributes }\end{array}$ & $0.01(0.84)$ & $0.09(0.14)$ & $0.01(0.88)$ & $0.00(0.93)$ & $0.02(0.73)$ & $0.02(0.73)$ \\
\hline Idealized behaviors & $0.02(0.69)$ & $0.03(0.60)$ & $0.03(0.54)$ & $0.02(0.71)$ & $0.03(0.64)$ & $0.00(0.98)$ \\
\hline \begin{tabular}{|l|} 
Inspirational \\
motivation \\
\end{tabular} & $0.38(\mathbf{0 . 0 0 0} * *)$ & $0.20(\mathbf{0 . 0 0 2} * *)$ & $0.34(\mathbf{0 . 0 0 0} * *)$ & $0.39(\mathbf{0 . 0 0 0} * *)$ & $0.37(\mathbf{0 . 0 0 0} * *)$ & $0.39(\mathbf{0 . 0 0 0} * *)$ \\
\hline \begin{tabular}{|l|}
$\begin{array}{l}\text { Intellectual } \\
\text { stimulation }\end{array}$ \\
\end{tabular} & $0.55(\mathbf{0 . 0 0 0} * *)$ & $0.46(\mathbf{0 . 0 0 0} * *)$ & $0.53(\mathbf{0 . 0 0 0} * *)$ & $0.43(\mathbf{0 . 0 0 0} * *)$ & $0.42(\mathbf{0 . 0 0 0} * *)$ & $0.55(\mathbf{0 . 0 0 0} * *)$ \\
\hline \begin{tabular}{|l}
$\begin{array}{l}\text { Individualized } \\
\text { consideration }\end{array}$ \\
\end{tabular} & $0.13(\mathbf{0 . 0 4})$ & $0.00(0.90)$ & $0.18(\mathbf{0 . 0 0 4} * *)$ & $0.24(\mathbf{0 . 0 0 0} * *)$ & $0.20(\mathbf{0 . 0 0 2} * *)$ & $0.17(\mathbf{0 . 0 0 6 * * )}$ \\
\hline $\begin{array}{l}\text { Total } \\
\text { Transformational } \\
\text { leadership style }\end{array}$ & $0.34(\mathbf{0 . 0 0 0} * *)$ & $0.23(\mathbf{0 . 0 0 0} * *)$ & $0.35(\mathbf{0 . 0 0 0} * *)$ & $0.34(0.000 * *)$ & $0.34(\mathbf{0 . 0 0 0} * *)$ & $0.37(\mathbf{0 . 0 0 0} * *)$ \\
\hline $\begin{array}{l}\text { B. Transactional } \\
\text { leadership style } \\
\text { Contingent reward }\end{array}$ & $\begin{array}{c}0.20 \\
(\mathbf{0 . 0 0 1} * *)\end{array}$ & $0.23(\mathbf{0 . 0 0 0} * *)$ & $0.21(\mathbf{0 . 0 0 0} * *)$ & $0.20(\mathbf{0 . 0 0 2} * *)$ & $0.18(\mathbf{0 . 0 0 4} * *)$ & $0.23(\mathbf{0 . 0 0 0} * *)$ \\
\hline $\begin{array}{l}\text { Active management } \\
\text { by exception }\end{array}$ & $0.41(\mathbf{0 . 0 0 0} * *)$ & $0.33(\mathbf{0 . 0 0 0} * *)$ & $0.51(\mathbf{0 . 0 0 0} * *)$ & $0.37(\mathbf{0 . 0 0 0} * *)$ & $0.41(\mathbf{0 . 0 0 0} * *)$ & $0.47(\mathbf{0 . 0 0 0} * *)$ \\
\hline $\begin{array}{l}\text { Total Transactional } \\
\text { leadership style }\end{array}$ & $0.35(\mathbf{0 . 0 0 0} * *)$ & $0.34(\mathbf{0 . 0 0 0} * *)$ & $0.40(\mathbf{0 . 0 0 0} * *)$ & $0.33(\mathbf{0 . 0 0 0} * *)$ & $0.34(\mathbf{0 . 0 0 0} * *)$ & $0.40(\mathbf{0 . 0 0 0} * *)$ \\
\hline $\begin{array}{l}\text { C. Laissez-faire } \\
\text { leadership style } \\
\text { Passive } \\
\text { management by } \\
\text { exception }\end{array}$ & $0.42(\mathbf{0 . 0 0 0} * *)$ & $0.33(\mathbf{0 . 0 0 0} * *)$ & $0.44(\mathbf{0 . 0 0 0} * *)$ & $0.43(\mathbf{0 . 0 0 0} * *)$ & $0.51(\mathbf{0 . 0 0 0 * * )}$ & $0.49(\mathbf{0 . 0 0 0} * *)$ \\
\hline $\begin{array}{l}\text { Laissez-faire } \\
\text { leadership } \\
\end{array}$ & $0.45(\mathbf{0 . 0 0 0} * *)$ & $0.33(\mathbf{0 . 0 0 0} * *)$ & $0.47(\mathbf{0 . 0 0 0} * *)$ & $0.44(0.000 * *)$ & $0.47(\mathbf{0 . 0 0 0} * *)$ & $0.52(\mathbf{0 . 0 0 0} * *)$ \\
\hline $\begin{array}{l}\text { Total Laissez-faire } \\
\text { leadership style }\end{array}$ & $0.49(\mathbf{0 . 0 0 0} * *)$ & $0.33(\mathbf{0 . 0 0 0} * *)$ & $0.51(\mathbf{0 . 0 0 0} * *)$ & $0.49(\mathbf{0 . 0 0 0} * *)$ & $0.56(\mathbf{0 . 0 0 0} * *)$ & $0.57(\mathbf{0 . 0 0 0} * *)$ \\
\hline
\end{tabular}

attachment to head nurse was the highest agreement Mean (15.77) while the lowest Mean was internalization of head nurse (11.56).

was the highest level of loyalty to head nurse $(87.5 \%)$ while the internalization $(9.2 \%)$ was the lowest level of loyalty to head nurse. leadership style 
Table (5): correlation between leadership styles as perceived by the staff nurses. This table showed that there was highly significant $(\mathrm{p} \leq 0.01)$ and statistically significant $(\mathrm{P}<0.05)$ correlation between leadership styles and loyalty as perceived by the staff nurses.

Table (6): Correlation between outcome of leadership (extra effort, satisfaction and effectiveness) as perceived by the staff nurses and their loyalty $(n=240)$

\begin{tabular}{|l|c|c|c|c|c|c|c|c|}
\hline \multirow{2}{*}{ Loyalty subscale } & \multicolumn{7}{|c|}{ The studied nurses (n=270) } \\
\cline { 2 - 9 } & $\mathbf{E x t r a}$ effort & \multicolumn{2}{|c|}{ Satisfaction } & \multicolumn{2}{c|}{ Effectiveness } & \multicolumn{2}{c|}{ Total outcome } \\
\hline $\begin{array}{l}\text { Dedication to } \\
\text { head nurse }\end{array}$ & 0.45 & $0.000^{* *}$ & 0.48 & $0.000^{* *}$ & 0.44 & $0.000^{* *}$ & 0.50 & $0.000^{* *}$ \\
\hline $\begin{array}{l}\text { Extra effort for } \\
\text { head nurse }\end{array}$ & 0.35 & $0.000^{* *}$ & 0.45 & $0.000^{* *}$ & 0.30 & $0.000^{* *}$ & 0.39 & $0.000^{* *}$ \\
\hline $\begin{array}{l}\text { Attachment to } \\
\text { head nurse }\end{array}$ & 0.39 & $0.000^{* *}$ & 0.40 & $0.000^{* *}$ & 0.32 & $0.000^{* *}$ & 0.40 & $0.000^{* *}$ \\
\hline $\begin{array}{l}\text { Identification } \\
\text { with head nurse }\end{array}$ & 0.41 & $0.000^{* *}$ & 0.46 & $0.000^{* *}$ & 0.35 & $0.000^{* *}$ & 0.44 & $0.000^{* *}$ \\
\hline $\begin{array}{l}\text { Internalization } \\
\text { of head nurse's } \\
\text { values }\end{array}$ & 0.44 & $0.000^{* *}$ & 0.47 & $0.000^{* *}$ & 0.39 & $0.000^{* *}$ & 0.47 & $0.000^{* *}$ \\
\hline $\begin{array}{l}\text { Total loyalty } \\
\text { score }\end{array}$ & 0.47 & $0.000^{* *}$ & 0.52 & $0.000^{* *}$ & 0.42 & $0.000^{* *}$ & 0.51 & $0.000^{* *}$ \\
\hline
\end{tabular}

Table (6): Correlation between outcome of leadership (extra effort, satisfaction and effectiveness) as perceived by the staff nurses and their loyalty. This table revealed that there was highly statistically significant correlation between outcome of leadership (extra effort, satisfaction and effectiveness) and their loyalty.

\section{Discussion}

Meanwhile, several reasons for increasing the nursing staff turnover that exist within healthcare systems. Thus, the current study aimed at investigating the relations between the leadership style of head nurses and the loyalty of nursing staff at Mansoura Health Insurance Hospital through; determining head nurses' leadership styles, identifying the levels of nursing staff loyalty, exploring the relation between leadership styles and nursing staff loyalty at Mansoura Health Insurance Hospital.
The correlation between leadership styles and loyalty

The current study revealed the change between opinion of head nurses and staff nurses concerning leadership styles there was statistically important variance between the head nurses and staff nurses regarding inspiration motivation of transformation leadership style but there was no statistically significant difference regarding others domains leadership styles. From point of view this may be related to that the head nurse talks optimistically about the future, instills pride in nursing staff for being associated with her, discusses in specific terms who is responsible for achieving performance targets and she don't wait for things to go wrong before taking action.

This results agree with, study of Byrne (2011)who revealed that a positive relationship among transformational leadership, and a negative relationship among transactional leadership, and also from the researcher point of view all of 
these results indicate the effect of each leadership style on the nursing staff's loyalty and latter affecting on their level of gratification. In the same line (Vizzuso, 2015) found that if the head nurses use more transformational leadership, the nursing staff may have the higher level of the loyalty to the head nurse.

So, the researcher like, (Kasper et al., 2012) who reported that head nurse must be consider that transformational leadership nurses follow head nurse who inspire them, head nurse with vision and passion can achieve great things but must maintain personal integrity, be willing to stand up and be counted, and use ceremonies, rituals, and other types of cultural symbolism to maintain motivation.

And also, these findings was show by (Anyango,2015) who investigate the effect of different leadership styles transformational, transactional, and laissez-faire leadership styles on nursing staff' loyalty and found that the transformational leadership style were found to be strongly correlated with both measures of nursing staff loyalty.

The current study showed the correlation between leadership styles as perceived by the staff nurses and loyalty where; there highly statistically significant relationship between leadership styles as perceived by the staff nurses and loyalty except for idealized influence and idealized behavior of transformational leadership style.

This results agree with, Zhenxiong et al (2001) who reported in his study that investigated the relationship between loyalty to head nurse and leadership styles. The results indicate that loyalty to head nurse is positively related to leadership styles. Loyalty to head nurse explained variance of leadership that explained by hospital commitment. The results also confirm the previous findings that the loyalty to head nurse dimensions were significantly associated with nursing staff concerns, while the loyalty to head nurse dimensions were not.

The result also clearly indicates that transformational leadership is correlated with nursing staff loyalty. This study revealed that transformational head nurse's futuristic focus on creativity and innovation, and they are able to inspire synergistic environments that enhance collaboration among staff nurses. This result is consistent with (Alshammari, 2014) who found that transformation leadership was significantly and positively correlated with head nurse collaboration relationship. Transformational head nurse produce nurses feel more engaged, loyalty and more likely to be perceived them as important nursing staff in a transformational environment $(\boldsymbol{M}$

.Salanova et al 2011).

In contrast $\mathbf{Y u}$ (2010) in his study stated that leadership style had moderate and positive correlations with nursing staff's loyalty to head nurse, and positive correlations with the values of the head nurse. The rewarding and active management have the positive association to the head nurse and understanding the value of head nurse. The coefficients revealed that transformational leadership, idealized attributes can anticipate the loyalty of the nursing staff to head nurse.

The current study showed the correlation between outcome of leadership (extra effort, satisfaction and effectiveness) as perceived by the staff nurses and their loyalty to the head nurse this result revealed that there was highly statistically significant correlation between outcome of leadership and loyalty. According to study done at Taif governmental hospitals (Dariush et al., 2016) added that there is a statistically significant positive correlation between outcome of leadership and loyalty as perceived by the staff nurses. Whereas, the studied head nurses perceived that there is 
no statistically significant relationship between outcome of leadership and loyalty.

This result agree with Artz (2010) who found that the benefits are significant and positive determinants of nursing staff satisfaction with the outcome of leadership. Fringe benefit is also believed to have a profound impact on nursing staff loyalty. The current study shows a strong influence the satisfaction on nursing staff loyalty, which McNeese-Smith (2001) also studied confirm that there is a positive relationship between satisfaction with outcome of leader ship and nursing staff loyalty.

Loyalty of nursing staff:-

The current study according to the total mean score of loyalty as perceived by the staff nurses show that the highest score regard attachment to head nurse while the lowest regard internalization of head nurse. From point of view this may be related to nursing staff need to give their agreement on without regarding to the benefit or not, they may have the feeling of continuous in the working under their head nurses for a long time and they may feel the satisfaction.

This results agree with (Chen et a!.,2002) who discovered that the attachment to head nurse because of the desire of the nursing staff and their purposes to follow them. Beside, their purpose to continue in working with the head nurse, while internalization of head nurse's decrease due to the values and beliefs between the nursing staff and the head nurse.

In the same line, Zhou et al (2012) found that the attachment to head nurse fully mediates the relationship between nursing staff loyalty and head nurse. There is positive relationship between the style of the leadership style and the loyalty of the nursing staff loyalty to head nurse, with the engaging of the nursing staff to head nurse.
Furthermore this agree with, Walker (2005) who states that the hospital commitment as involving attachment nursing staff's loyalty to the head nurse , willingness to exert effort on behalf of the head nurse, degree of goal and value congruency with the head nurse, and desire to maintain membership. And also, (Padmavathy et al., 2012) concluded that if the attachment to head nurse is not positive towards hair nursing staff, the head nurse can never create nursing staff loyalty and hospital commitment. It would assert adverse effect and hospital productivity may suffer.

In the same line (Coughlan, 2005), who proposed that the possible causes that impact on the association of the nursing staff loyalty focused on head nurse's leadership is one essential element in the features of nursing staff who communicate with the nursing staff.

And also, this result agree with Cheng (2004) who states that the nursing staff attachment to head nurse when the head nurse provides the mercy to increase the feeling of the commitment. Thus, commitment increase and the loyalty enhanced from the nursing staff.

\section{Conclusion \\ In the light of present study, it was concluded that:}

There is a statistical relationship between the style of the leadership and the loyalty to head nurse at Mansoura Health Insurance Hospital. Also, Transformational leadership have the positive relationship with the loyalty of the nursing staff to head nurses

Transformational leadership was the dominant practiced style followed by laissez faire and transactional leadership style. The results revealed that transformational leadership anticipate the loyalty to head nurse. The head nurses perform more transformational leadership, the nursing staff will have higher loyalty to the head nurse. The stimulation 
behavior of leadership can anticipate the loyalty to head nurse.

\section{Recommendations}

In the light of the study findings, the following recommendations were suggested:

\section{Recommendation related to head nurse} toward nursing staff :-

1. The head nurse should has the consciousness of the essential element for the nursing staff and the hospitals, and stimulate the nursing staff to have opportunities around them effectively.

2. The head nurses should own special visions and the way to develop the plans for the nursing staff, the members and hospitals.

3. The head nurses should own the innovation feeling; they should stimulate the nursing staff to get more opportunities to accomplish the performance according to the expectations.

4. The head nurses should respect the nurses is to make the positive relationship between head nurse and nursing staff.

Recommendation related to the hospital administrators:-

1. The hospital can present the program based on the training of the leadership for enhancing the head nurse's leadership styles based on nursing staff's needs and hospital needs.

2. The hospital and head nurses should involve nursing staff in making decision, developing the leadership, presenting training and presenting the facilitation to the teamwork. Besides, the practices should be associated with the rewarding or the feedback system in the hospital to satisfy the needs of the nursing staff for developing the loyalty of the nurse.

\section{Reference}

1. Alshammari (2014). Nursing leadership in the ministry of health hospitals of Saudi Arabia. Doctor of Philosophy (PhD) School of Health Sciences College of Science, Engineering and Health RMIT University May 2014:p 232242.https://researchbank.rmit.edu.au/es erv/rmit:160740/Alshammari.pdf.

2. Anyango CA. (2015). The effect of leadership styles on employees' performance at Bank of Africa, Kenya. The Open University Of Tanzania.

3. Artz, B.( 2010). Fringe benefits and job satisfaction. International Journal of Manpower, 31(6): 626-644.

4. Azaare J, and Gross J (2011): The nature of leadership style in nursing management. British Journal of Nursing, 20(11), 672-680.

5. Bass B. and Riggio R.E. (2006). Transformational Leadership ,2nd ed, Taylor and Frances library, Lawrence Erlbaum Associates, Mahwah, New Jersy, London. pp150-167.

6. Bass BM \&Avolio B (2004). Multifactor leadership questionnaire, third edition, manual and sampler set. Redwood City, CA: Mind Garden, 1317.

7. Byrne D (2011). The relationship of leadership style of the department head to nursing faculty professional satisfaction and organizational commitment. Dissertation. faculty of the graduate school at the university of Missouri-Columbia.

8. Chen ZX, Tsui AS \&Farh J-L (2002). Loyalty to supervisor vs. organizational commitment: Relationships to employee performance in China. Journal of Occupational and Organizational Psychology, 75: (3), 339-356.

9. Cheng, L. C. (2004). The Influence of Human Resource Management Practices on the Retention of Core 


\begin{tabular}{l}
\hline Employees of Australian \\
Organizations: An Empirical Study. \\
Unpublished doctoral dissertation, \\
Murdoch University. \\
10. Coughlan R (2005). Employee loyalty \\
as adherence to shared moral values. \\
Journal of Managerial Issues, 43-57. \\
11. Dariush L, Choobdar G, Valadkhani \\
$\mathbf{P}$ \&Mehrali E(2016).Leadership \\
Styles Facilitating Organizational \\
Commitment of Employees. \\
International Journal of Economics, \\
640-655.
\end{tabular}

12. Ding D, Lu H, Song Y \& Lu Q (2012). Relationship of Servant Leadership and Employee Loyalty: The Mediating Role of Employee Satisfaction. iBusiness, 04: (03), 208215.

13. Jaramillo, D. B. Grisaffe, L. B. Chonko and J. A. Roberts(2009): "Examining the Impact of Servant Leadership on Salesperson's Turnover Intention," Journal of Personal Selling \& Sales Management, Vol. 29, No. 4, pp. 351-365.

14. Glanz J(2002). Finding your leadership style: A guide for educators, ASCD.

15. Kasper, H., Muehlbacher ， J., Kodydek , G., and Zhang, L. (2012). Fringe benefits and loyalty on the Chinese labor market a trend towards higher individual and performanceorientation a case study focusing on technology companies in the shanghai region. Journal of Technology Management in China, 7(2), 164-176.

16. Kasper, H., Muehlbacher , J., Kodydek , G., and Zhang, L. (2012). Fringe benefits and loyalty on the Chinese labor market a trend towards higher individual and performanceorientation a case study focusing on technology companies in the shanghai region. Journal of Technology Management in China, 7(2), 164-176.
17. Kyle ,LaMalfa, (2007): the Top 11 Ways to Increase Your Employee Loyalty, Business Week Technology Research, pp1-2.

18. Lee H-C \& Chuang T-h (2009). The impact of leadership styles on job stress and turnover intention: Taiwan insurance industry as an example. Effects of Leadership Style on Organizational Performance: A Survey of Selected Small Scale Enterprises in Ikosi-Ketu Council Development Area of Lagos State, Nigeria. Australian Journal of Business and Management Research, 1: (7), 100-111.

19. M. L. Voon, M. C. Lo, K. S. Ngui and N. B. Ayob, (2011). The Influence of Leadership Styles on Employee Job Satisfaction in Public Sector Organization Malaysia," International Journal of Business, Vol. 2, No. 1, pp. 24-32.

20. Marshall ES (2010). Transformational leadership in nursing: From expert clinician to influential leader, Springer Publishing Company.

21. McNeese-Smith, D. K. (2001).A nursing shortage: Building organizational commitment among nurses. Journal of Health Care Management, 46, 173-186.

22. Messmer PR \& Turkel MC (2010). Magnetism and the Nursing Workforce. Annual Review of Nursing Research, 28: (1), 233-252.

23. Padmavathy et al. (2012). Measuring effectiveness of customer relationship management in Indian retail banks. International Journal of Bank Marketing, 246 - 266.

24. Phaneuf W, (2013) . Employee loyalty doesn't $t$ equal longevity. The Training Source.

Retrievedfromhttp://www.leadingforlo yalty.com/employee_loyalty.html.

25. Salanova, Lorente, Chambel, \& Martinez (2011). Linking transformational leadership to nurses' 
extra-role performance: the mediating role of self-efficacy and work engagement. Journal of Advanced Nursing, 67, 2011. 2256-2266.

26. Sullivan EJ, Garland G (2010). Practical Leadership and Management in Nursing. Pearson Education Limited, Harlow.

27. Vizzuso JD (2015). Leadership strategies to influence employee engagement in health care.

28. Walker, R. a. (2005). Public Management Reform and Organizational Performance: An empirical assessment of the $\mathrm{u} \mathrm{K}$ labor Government's Public Service Improvement Strategy. Working Paper, Center for Local and Regional Government Research, Cardiff University .

29. Yang LH (2016). How the Transformational Leadership Style of Superintendents is Associated With Employees' Organizational Commitment via the Mediating Effect of Extrinsic Motivation Within Nursing Homes for Disabled People in Taiwan.
30. Yu $\quad \mathbf{X}$ (2010). Exploring the relationship between supervisor's leadership style and employee loyalty. Master of Science Degree in Applied Psychology, the Graduate School University of Wisconsin-Stout.

31. Zhenxiong Chen, Anne s. Tsui, JiingLih Larry Farh (2001). Loyalty to Supervisor Vs. Organizational Commitment: Relationships to Employee Performance in China, Journal of Occupational and Organizational Psychology, 75, 339356.

32. Zhou, Z., Zhang, Q., Su, C. and Zhou, N. (2012). How do brand communities generate brand relationships? Intermediate mechanisms. Journal of Business Research 65(7): 890-895. Hung and Tsai 614. 